\title{
Effects of zinc, boron and sulfur on grain yield, activity of some antioxidant enzymes and fatty acid composition of rapeseed (Brassica napus $L_{\text {.) }}$
}

\author{
Tayebeh SHOJA ${ }^{1}$, Majid MAJIDIAN ${ }^{1 *}$, Mohammad RABIEE $^{2}$
}

Received October 22, 2017; accepted February 22, 2018.

Delo je prispelo 22. oktobra 2017, sprejeto 22. februarja 2018.

\begin{abstract}
A field experiment was conducted to study the effects of elements zinc ( $\mathrm{Zn})$, boron (B) and sulfur (S) and their interactions on quantitative and qualitative agronomic characteristics of rapeseed. Minimum grain oil and seed yield were obtained from control treatments and the highest seed yield were obtained from $\mathrm{S}+\mathrm{B}+\mathrm{Zn}$ treatments. The maximum of oleic acid (229.6 $\mathrm{mg} \mathrm{g}^{-1}$ ) and linolenic acid $\left(27.14 \mathrm{mg} \mathrm{g}^{-1}\right)$ were obtained from $\mathrm{B}+\mathrm{Zn}+\mathrm{S}$ treatment. Maximum of linoleic acid $\left(55.55 \mathrm{mg} \mathrm{g}^{-1}\right)$ were obtained from $\mathrm{B}+\mathrm{Zn}$ treatment. However, the highest superoxide dismutase activity was obtained from $\mathrm{S}+\mathrm{B}+\mathrm{Zn}$ treatments 10.24 unit $\mathrm{mg}^{-1}$ and the highest peroxidase activity were obtained from $\mathrm{Zn}$ treatment $0.87 \mu \mathrm{mol} \mathrm{g}^{-1} \mathrm{FM}$ min. Regard to this experiment results, application of $\mathrm{B}, \mathrm{S}$ and $\mathrm{Zn}$ fertilizers with NPK fertilizer can help to increase the yield and yield components in rapeseed. Also fatty acids composition of rapeseed are influenced by nutrients and since quality of edible oils depends on unsaturated fatty acids, especially linoleic and linolenic acids and these acids are essential fatty acids for the human body that must be supplied through diet. Therefore this research showed that we are not only able only to increase oil yield but also oil quality with desired fatty acid composition.
\end{abstract}

Key words: erucic acid; grain oil; linoleic acid; superoxide dismutase; rapeseed
IZVLEČEK

\author{
UČINKI CINKA, BORA IN ŽVEPLA NA PRIDELEK \\ ZRNJA, AKTIVNOST NEKATERIH \\ ANTIOKSIDACIJSKIH ENCIMOV IN SESTAVO \\ MAŠČOBNIH KISLIN OLJNE OGRŠČICE (Brassica \\ napus $\mathbf{L}$.)
}

Izveden je bil poljski poskus za preučevanje učinkov $\mathrm{Zn}, \mathrm{B}$ in $\mathrm{S}$ ter njihovih interakcij na količinske in kakovostne agronomske lastnosti oljne ogrščice. Najmanjša pridelka zrnja in olja sta bila dobljena $v$ kontrolnem obravnavanju in največja pri obravnavanju $\mathrm{S}+\mathrm{B}+\mathrm{Zn}$. Največ oleinske $\left(229.6 \mathrm{mg} \mathrm{g}^{-1}\right)$ in linolenične kisline $\left(27.14 \mathrm{mg} \mathrm{g}^{-1}\right)$ je bilo pri obravnavanju $\mathrm{B}+\mathrm{Zn}+\mathrm{S}$. Največ linolenične kisline $\left(55.55 \mathrm{mg} \mathrm{g}^{-1}\right)$ je bilo doseženo pri $\mathrm{B}+\mathrm{Zn}$ obravnavi. Največja aktivnost superoksid dizmutase je bila pri $\mathrm{S}+$ $\mathrm{B}+\mathrm{Zn}$ obravnavi $\left(10.24\right.$ enot $\left.\mathrm{mg}^{-1}\right)$ in največja aktivnost peroksidaze pri obravnavi samo s cinkom $\left(0.87 \mu \mathrm{mol} \mathrm{g}^{-1} \mathrm{FM}\right.$ min). Glede na rezultate raziskave sklepamo, da uporaba $B, S$ in Zn gnojil s NPK gnojili lahko pomaga povečati pridelek in njegove dele pri oljni ogrščici. Gnojila vplivajo tudi na sestavo maščobnih kislin v olju, kar vpliva na kakovost jedilnega olja, ki je odvisna od vsebnosti nezasičenih maščobnih kislin, predvsem linoleične in linolenične, ki sta za človeka esencialni in jih mora dobiti s hrano.V tem pogledu je raziskava pokazala, da nismo sposobni le povečati pridelka olja ampak tudi dosegati željeno sestavo maščobnih kislin v njem.

Ključne besede: erucična kislina; olje v zrnu; linoleična kislina; superoksid dismutaza; oljna ogrščica

\section{INTRODUCTION}

Rapeseed (Brassica napus L. ssp. napus) is grown in different agro-climatic zones of the world, differing in soil nutrient status (Bybordi \& Mamedov, 2010). Canola is an important agricultural crop, grown primarily for oil production, but also as a valuable break-crop in cereal crop rotations (Gammelvind et al., 1996).

Zinc is a structural part of several enzymes or is necessary for enzyme activation; thus $\mathrm{Zn}$ deficiency also affects carbohydrate metabolism, damages pollen

\footnotetext{
1 University of Guilan, Faculty of Agricultural Sciences, Department of Agronomy and Plant Breeding, Rasht, Iran; *e-mail: ma_majidian@guilan.ac.ir

2 Rice Research Institute of Iran, Rasht, Iran

Paper is part of a MSc thesis Tayebeh Shoja
} 
structure, and decreases the yield (Das et al., 2005; Pandy et al., 2006; Fang et al., 2008). Applying zinc to a $\mathrm{Zn}$-deficient soil could also advance the seed yield of rapeseed (Singh Grewal et al., 1997; Singh Grewal \& Grahma, 1999). Zinc is a cofactor of over 300 enzymes and proteins and has an early and effect on cell division and protein synthesis (Marschner, 1986). Low solubility of zinc in soils rather than low total amount of $\mathrm{Zn}$ is the main reason for the general occurrence of $\mathrm{Zn}$ deficiency problem in crop plants (Cakmak, 2008). High seed- Zn has very vital physiological roles during germination and seedling growth (Cakmak, 2008). The review by Cakmak (2008) provides further reasons and relevant research for profit of high seed $\mathrm{Zn}$ on plant growth.

Rapeseed, one of the main oil crops in Iran as well as in the world, is sensitive to B deficiency (Chu et al., 1996). Boron plays roles in structure and cell wall synthesis, and possibly membrane stability (Matoh 1997; Goldbach et al., 2001; Brown et al., 2002; Iwai et al., 2006). It promotes the strength and rigidity of cell wall structure and therefore, supports the figure and power of the plant cell (Brown et al., 2002). Furthermore, boron is maybe concerned in the integrity of the plasma membrane (Brown et al., 2002: Cara et al., 2002; Dordas \& Brown, 2005). B deficiency causes irregular development of reproductive organs (Dell \& Huang, 1997; Huang et al., 2000), and reduces plant yield (Chen et al., 2005; Nabi et al., 2006). Boron is involved in carbohydrates metabolism and it is basically necessary for protein synthesis, pollen germination and seed and cell wall development.

Boron and $\mathrm{Zn}$ deficiencies are more possible early in the season for the reason that the translocation of elements from the root to the aboveground part may not be sufficient before leaf expansion (Neilsen et al., 2004). Applications $\mathrm{Zn}$ and $\mathrm{B}$ have been experimental to have a positive effect on chlorophyll contents in B - and Zn deficient plants (Kaya \& Higgs, 2002). Sinha et al. (2000) noted a synergistic interaction among $\mathrm{Zn}$ and B in black mustard (Brassica nigra L.) when both nutrients were also in small or excess supply.

Sulfur is main nutrient in crop production. Deficiency of $\mathrm{S}$ affected all crop, from forage to oilseed, but the clearest effects have been seen in canola for the cause that of its high S required (Malhi et al., 2005). Rapeseed has a high protein concentration with a high proportion of the amino acids as cysteine and methionine (Anderson 1975; Clandinin, 1981; Grant \& Bailey, 1993). It has been experimental proved that rapeseed requires 3-10 times more $S$ than barley (Bole \& Pitman, 1984). Rapeseed has a high requirement for $S$ to optimize yield (Grant \& Bailey, 1993), i.e., about $1.5 \mathrm{~kg}$ of $\mathrm{S}$ to manufacture $100 \mathrm{~kg}$ of grain (Nyborg et al., 1974). For maximum seed yield rapeseed, the $S$ requirement is greater than that for cereals (Hamm 1967; Bole \& Pitman, 1984). Therefore, rapeseed is more likely to respond to $\mathrm{S}$ fertilization. Sulphate-S application is reported to increase concentration of oil in rapeseed seed (Nuttal et al., 1987; Malhi \& Gill 2002; Grant et al., 2003), but in some reported a decrease (Wetter et al., 1970) or no alter (Ridley, 1973) was found. Rapeseed oil has a lower level of saturated fats (only $6 \%$ ) than any other edible oil plant and also has a high amount of un-saturated fat containing a good combine of both poly and monounsaturated fats. Relative proportion of different fatty acid determines the quality of edible oil. Higher percentage of polyunsaturated fatty acid is considered beneficial for lowering cholesterol in human body (Cunnae, 1995). Sulfur increases the percentage of oil content of the seed (Chaudhry et al., 1992), glucosinolate content and erucic acid (Marschner, 1986).

Most researchers have studied the effect of a single element fertilizer on the crop yield, whereas few have payed attention on the function of the combined applications of nutrients in improving the yield. In this present study, the effects of Zn, B, S and their interactions on the quality and seed yield rapeseed were examined.

\section{MATERIALS AND METHODS}

The field experiment was conducted at University of

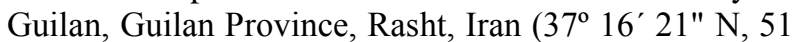
o 3' 36" E), during 2014 cropping seasons. Prior to the beginning of experiment, soil samples were taken to determine the chemical and physical properties. A composite soil samples were collected at a depth of 0 $30 \mathrm{~cm}$. The chemical properties of the clay loam were: $\mathrm{pH}\left(1: 2\right.$ soil: $\left.\mathrm{H}_{2} \mathrm{O}\right) 6.9$, total nitrogen $0.12 \%$, available $\mathrm{P}$ $14.9 \mathrm{mg} \mathrm{kg}^{-1}$, available $\mathrm{K} 202 \mathrm{mg} \mathrm{kg}^{-1}$, available $\mathrm{Zn}$
$0.94 \mathrm{mg} \mathrm{kg}{ }^{-1}$, available $\mathrm{B} 0.02 \mathrm{mg} \mathrm{kg}{ }^{-1}$, soluble $\mathrm{SO}_{4}$ 0.64 meq $1^{-1}$, EC $0.255 \mathrm{dS} \mathrm{m}^{-1}$.

After ploughing and disk harrowing twice, the land was flatted by leveler and then plots were prepared. The experiment with completely randomized block design was performed with eight treatments in three replicates. Treatment consisted control, Zn, B, S, Zn + S, Zn + B, $B+S$, and $S+B+Z n$. Sulfur treatment added as sulfur flower at the rate $100 \mathrm{~kg} \mathrm{ha}^{-1}$ in plots and mixed with 
surface soil before seed sowing. Boron was added as $\mathrm{H}_{3} \mathrm{BO}_{3}$ at the rate of $8 \mathrm{~kg} \mathrm{ha}^{-1}$, zinc was added as $\mathrm{ZnSO}_{4} \cdot 7 \mathrm{H}_{2} \mathrm{O}$ at the rate of $30 \mathrm{~kg} \mathrm{ha}^{-1}$ were applied in plots.

The plots had $5 \mathrm{~m}$ length and $2.25 \mathrm{~m}$ width consisted of 8 rows. Between all plots, $1.5 \mathrm{~m}$ distance was kept to eliminate all influenced of lateral water movement. According to results of soil analysis $150 \mathrm{~kg} \mathrm{ha}^{-1}$ ammonium phosphate, $150 \mathrm{~kg} \mathrm{ha}^{-1}$ potassium, and $120 \mathrm{~kg} \mathrm{ha}^{-1}$ urea was used. All of ammonium phosphate, potassium and one third of urea were distributed in plots and mixed with surface soil before seed sowing. Side dressings of nitrogen fertilizer were applied at bolting and flowering stages.

'Hyola 401' a double low (low erucic acid and low glucosinolate) rapeseed (B. napus L.) cultivar was used.

When rapeseed commenced flowering, twelve plants in each plot were randomly marked with tags for analysis of yield components, including thousand-seed mass, seeds number per silique and siliques number per plant. The remaining plants in each plot were harvested to measure the plots seed yield at maturity.

At $80 \%$ flowering $(\mathrm{BBCH}, 67)$, five upper leaves were collected for determined of $\mathrm{Zn}, \mathrm{B}$ and $\mathrm{S}$ content of leaves. Leaves were washed with distilled water, dried at $70{ }^{\circ} \mathrm{C}$ for $48 \mathrm{~h}$, ground to pass $1 \mathrm{~mm}$ sieve, stored in bags before analyses, and analyzed. Zinc was determined by atomic absorption spectrophotometry
(AAS) (Perkin Elmer model 3030). Boron was measured with the curcumin spectrophotometric method (Lieten, 2002). Sulfur was measured with the turbidimetric method (Benton, 2001).

Oil seed amount was measured by soxhlet (Soxtec system HT 1043) method. The fatty acid compositions of the canola seed oils were determined by gas chromatography (model, Unicam 4600).

\subsection{Enzymes Assay}

Superoxide dismutase activity was determined by measuring its ability to inhibit the photoreduction of nitro blue tetrazolium according to the methods of Beauchamp and Fridovich (1971).

Peroxidase activity was assayed in leaves by the oxidation of guaiacol in the presence of $\mathrm{H}_{2} \mathrm{O}_{2}$. The increase in absorbance was recorded at $470 \mathrm{~nm}$ (Chance \& Maehly, 1955).

\subsection{Statistical Analysis}

A completely block randomized design in three replications was used. The statistical analyses of data were performed by ANOVA procedure from SAS 9.1 (SAS Institute, United States). Differences between means were evaluated by the least significant difference methods. The 0.05 and 0.01 probability values were used to determine significant difference.

\section{RESULTS AND DISCUSSION}

\subsection{Effects of $\mathrm{B}, \mathrm{Zn}, \mathrm{S}$ and their interactions on seed yield}

Statistical analysis of the data on seed yield revealed significant difference among treatments $(p<0.01)$ (Table 1). The highest seed yield was produced from B $+\mathrm{Zn}+\mathrm{S}$ treatment. The minimum seed yield was recorded for control (Table 2). Results showed in the three single nutrient treatments the application of B, $\mathrm{Zn}$ and $S$ significantly increased the seed yield over that of the control (Table 2). This indicated that $\mathrm{B}, \mathrm{Zn}$ and $\mathrm{S}$ fertilizer played a very important role in promoting the seed yield of 'Hyola 401'. The application of B with S or $\mathrm{Zn}$ fertilizer increased the seed yield by a future $25 \%$ and $19.7 \%$, respectively, compared to that of the control. Elements of $\mathrm{Zn}+\mathrm{S}$ without $\mathrm{B}$ increased the seed yield for $23 \%$ (Table 2). The effect of B $+\mathrm{Zn}+\mathrm{S}$ was the biggest, indicating that the combined application of the three nutrients was beneficial for the seed yield of rapeseed. 
Tayebeh SHOJA et al.

Table 1: Mean squares from analysis of variance of yield, yield components, seed oil, S, Zn and B contents of rapeseed

\begin{tabular}{|c|c|c|c|c|c|c|c|c|c|}
\hline \multirow[t]{2}{*}{ S.O.V } & \multirow[t]{2}{*}{ df } & \multicolumn{8}{|c|}{ Mean Squares } \\
\hline & & Seed yield & $\begin{array}{l}1000 \\
\text { seed } \\
\text { mass }\end{array}$ & $\begin{array}{c}\text { Seed } \\
\text { number } \\
\text { per } \\
\text { Silique }\end{array}$ & $\begin{array}{l}\text { Siliques } \\
\text { number } \\
\text { per plant }\end{array}$ & Seed oil & S content & $\begin{array}{c}\mathrm{Zn} \\
\text { content }\end{array}$ & $\begin{array}{c}\text { B } \\
\text { content }\end{array}$ \\
\hline Block & 2 & 26117.41 & 0.005 & 0.29 & 7777.54 & 7.73 & 4726.52 & 25.04 & 87.16 \\
\hline Treatment & 7 & $418462.67 * *$ & $0.39 * *$ & $9.18^{* *}$ & $4685.8 * *$ & $27.53 * *$ & $115889.71 * *$ & $110.77 * *$ & $54.59 * *$ \\
\hline Error & 14 & 30539.34 & 0.0028 & 0.29 & 259.54 & 0.34 & 1391.08 & 1.56 & 2.89 \\
\hline $\mathrm{Cv}(\%)$ & - & 18.8 & 16.1 & 13.9 & 16.1 & 15.5 & 6.5 & 13.1 & 10.4 \\
\hline
\end{tabular}

ns and *,**: non-significant and significant at $5 \%$ and $1 \%$ probability levels, respectively

Mei et al., (2009) showed that seed yield of the B + Mo $+\mathrm{Zn}$ treatment was the highest in all treatment, $68.1 \%$ above the control. Fang et al. (2008) showed that zinc increased seed yield because it can give an optimum effect on photosynthesis rate. The increase in yield with $\mathrm{Zn}$ might have been the results of increased branch number per plant, siliques number per plant, seed number per silique and thousand-seed mass. In proceed to the previous studies (Cakmak et al., 1999), all methods of $\mathrm{Zn}$ application for plants significantly increased grain yield. Micronutrients increase photosynthesis rate and improves leaf area duration thus seed yield will be increased. Zinc plays important role in tryptophan biosynthesis, later in its role as precursor of auxin. Zinc is also found in phosphoenolpyruvate carboxylase structure.

Zhang (2001) also showed that the critical range of the B concentration corresponding to $90 \%$ of the maximum oilseed rape yield was $0.04-0.52 \mathrm{mg} \mathrm{kg}^{-1}$. Thus it is not unexpected that the plants showed $\mathrm{B}$ deficiency symptoms at the lack of $B$ even though a small amount of basal B was added to prevent complete loss of reproductive yield. One of the essential physiological roles of $\mathrm{B}$ in plants is to improve pollen tube growth and fertilization in reproductive growth (Dell \& Huang, 1997). Thus, B deficiency results in a typical symptom called "flowering without seed setting" (Liu, 1999). In the study, use of B increased the number of siliques per plant and seeds per silique, therefore resulting in a significant increase in the seed yield. This confirmed the important role of $\mathrm{B}$ in pollen development and fertilization reported earlier (Dell and Huang, 1997; Huang et al., 2000). Rapeseed has a high requirement for $\mathrm{S}$ to optimize yield (Grant \& Bailey, 1993), i.e., about $1.5 \mathrm{~kg}$ of $\mathrm{S}$ to produce $100 \mathrm{~kg}$ of seed (Nyborg et al., 1974). For high seed yield, the $S$ requirement for rapeseed is greater than that for cereals (Hamm, 1967; Bole and Pitman, 1984). Rapeseed responded to S fertilization through increasing number of siliques per plantand so increased yield (Table 2).

\subsection{Effects of $\mathrm{B}, \mathrm{Zn}, \mathrm{S}$ and their interactions on yield components:}

The components of seed yield were the number of siliques per plant, seeds per silique, and the thousand seed mass. As seen in Table 1 analysis of variance showed effects of fertilizer treatment on siliques number per plant, seeds number per silique, and the thousand seed mass were significant $(p<0.01)$ (Table 1). The highest siliques number per plant (319.7) was produced from $\mathrm{B}+\mathrm{Zn}+\mathrm{S}$ treatment and minimum (199.7) was recorded for control (Table 2). 
Effects of zinc, boron and sulfur on grain yield, ... fatty acid composition of rapeseed (Brassica napus L.)

Table 2: Effects of boron (B), zinc (Zn), sulfur (S), and their interactions on the seed yield, yield components, seed oil and $\mathrm{S}, \mathrm{Zn}$ and $\mathrm{B}$ content in leaf of rapeseed

\begin{tabular}{|c|c|c|c|c|c|c|c|c|}
\hline Treatment & $\begin{array}{l}\text { Seed yield } \\
\left(\mathrm{kg} \mathrm{ha}^{-1}\right)\end{array}$ & $\begin{array}{c}1000 \text { seed } \\
\text { mass }(\mathrm{g})\end{array}$ & $\begin{array}{c}\text { Seed } \\
\text { number per } \\
\text { silique }\end{array}$ & $\begin{array}{c}\text { Siliqua } \\
\text { number per } \\
\text { plant }\end{array}$ & $\begin{array}{l}\text { Seed oil } \\
(\%)\end{array}$ & $\begin{array}{l}\text { S content } \\
\left(\mathrm{mg} \mathrm{kg}^{-1}\right)\end{array}$ & $\begin{array}{l}\text { Zn content } \\
\left(\mathrm{mg} \mathrm{kg}^{-1}\right)\end{array}$ & $\begin{array}{l}\text { B content } \\
\left(\mathrm{mg} \mathrm{kg}^{-1}\right)\end{array}$ \\
\hline Control & $3860.6^{\mathrm{d}}$ & $4.82^{c}$ & $24.3^{\mathrm{d}}$ & $199.7^{\mathrm{c}}$ & $33.65^{f}$ & $223.97^{f}$ & $30.31^{\mathrm{g}}$ & $10.21^{\mathrm{f}}$ \\
\hline B & $4377.9^{\mathrm{bc}}$ & $4.86^{\mathrm{c}}$ & $27^{b c}$ & $227.7^{\mathrm{de}}$ & $37.89^{d}$ & $391.13^{c}$ & $34.99^{f}$ & $17.35^{\mathrm{bc}}$ \\
\hline $\mathrm{Zn}$ & $4091.6^{\mathrm{cd}}$ & $4.94^{\mathrm{dc}}$ & $25.7^{\mathrm{cd}}$ & $250.3^{\mathrm{cd}}$ & $35.47^{\mathrm{c}}$ & $490.53^{d}$ & $41.1^{c}$ & $13.3^{\mathrm{de}}$ \\
\hline $\mathrm{S}$ & $4496.1^{\mathrm{a}-\mathrm{c}}$ & $5.04^{\mathrm{cd}}$ & $27.3^{b}$ & $264^{b-d}$ & $39.37^{\text {cd }}$ & $730.5^{b}$ & $38.81^{\text {de }}$ & $12.87^{\mathrm{ef}}$ \\
\hline $\mathrm{B}+\mathrm{S}$ & $4808.7^{\mathrm{ab}}$ & $5.57^{b}$ & $27.7^{b}$ & $282.3^{\mathrm{a}-\mathrm{c}}$ & $40.02^{\mathrm{bc}}$ & $609.79^{c}$ & $37.6^{c}$ & $19.29^{b}$ \\
\hline $\mathrm{B}+\mathrm{Zn}$ & $4620.8^{\mathrm{ab}}$ & $5.17^{c}$ & $27.3^{b}$ & $272.7^{b-d}$ & $41.26^{\mathrm{ab}}$ & $559.96^{c}$ & $40.37^{\mathrm{cd}}$ & $16.64^{b c}$ \\
\hline $\mathrm{S}+\mathrm{Zn}$ & $4744.9^{\mathrm{ab}}$ & $5.58^{b}$ & $29.3^{\mathrm{a}}$ & $306.3^{\mathrm{ab}}$ & $40.54^{\mathrm{bc}}$ & $745.55^{\mathrm{ab}}$ & $49.49^{\mathrm{a}}$ & $16.01^{\mathrm{cd}}$ \\
\hline $\mathrm{B}+\mathrm{S}+\mathrm{Zn}$ & $4965^{\mathrm{a}}$ & $5.74^{\mathrm{a}}$ & $29.7^{\mathrm{a}}$ & $319.7^{\mathrm{a}}$ & $42.66^{\mathrm{a}}$ & $802.6^{\mathrm{a}}$ & $46.4^{b}$ & $24^{\mathrm{a}}$ \\
\hline
\end{tabular}

* Means followed by the same letter(s) in each column are not significantly different $(\mathrm{P}=0.05)$.

The application of B with $\mathrm{Zn}$ or S fertilizer increased the siliques number per plant by a further $41.4 \%$ and $37 \%$ respectively, compared to that of the control. The addition of $\mathrm{S}+\mathrm{Zn}$ without $\mathrm{B}$ also increased the siliques number per plant for $53.4 \%$ (Table 2). The effect of B + $\mathrm{Zn}+\mathrm{S}$ was the biggest $(60 \%)$, indicating that the combined application of the three nutrients was beneficial for the siliques number per plant of rapeseed. This beneficial effect might be due to interaction effect of sulphur, zinc, boron and their role in synthesis of IAA, metabolism of auxin and formation of chlorophyll synthesis.

Sulfur fertilizer effect on the plant height was increased due to more light penetration into plant canopy and increased the number of branches per plant and silique number per plant. Rathinavel et al. (2000) reported for flax (Linum usitatissium L.) that zinc transfered assimilates more effectively and directly affected flax capsule mass. Zinc is involved in synthesis of indole-3acetic acid. This hormone is the main factor preventing loss in the number of flax capsula, and $\mathrm{Zn}$ can also be used for preventing the losses of rapeseed siliquas. Also, the reason for that the potential loss of silique per plant, may be a poor pollination (Azizi et al., 2006). Based on the results of previous research the cause of decreased formation of male and female sexual organs and the lack of pollination processes is due to zinc deficiency. They attributed this to a decrease in the production of indole acetic acid (Brown et al., 1993). The researchers also stated that boron is essential element needed for pollen germination and pollen tube growth (Marschner, 1995). They believe that the low absorption of boron in the soil impairs the plant's pollination, resulting in plant sterility (Vitosh et al., 1997).

\subsection{Seed number per silique}

Seed number per silique is an important yield component, since the seeds are produced as storage organs. It seems that the number of seeds per silique is larger sink to store more materials there. The highest seed number per silique (29.7) was produced from B + $\mathrm{Zn}+\mathrm{S}$ treatment and minimum (24.3) was recorded for control (Table 2).

Increased seed number per silique as effect of zinc and boron fertilizer might be because of boron key role in translocation water and nutrients from the roots to the shoots (Rehem et al., 1998). Production of more chlorophyll and IAA which delayed plant senescence and thus prolonged the period of photosynthesis. This improves carbohydrate production and their transfer it to the growing seeds (Vitosh et al., 1997). Mc-Grath and Zhao (1996) and Roe et al. (1997) in their research showed that sulfur ratio of reproductive organs to the total dry matter increased. Sulfur deficiency inhibits the growth of reproductive organs and even leads to sterility of siliques.

Table 2 showes the effects of the single nutrient treatments of B, Zn, S as the increased seed number per silique, 12.3, 6 and $11.1 \%$, respectively. Also, all combined application of two nutrients resulted in a significant increase in the seed number per silique in comparison with the single nutrient application. The maximum seed number per siliques in comparison with the control indicates that the combined application of the three nutrients gives the best results $(22.2 \%)$ (Table 2). According to Brown et al. (1993) formation of male and female reproductive organs and pollination process are disturbed in $\mathrm{Zn}$ deficiency, which results in a severe 
reduction in plant yield, this is due to reduction of indol acetic acid (IAA) synthesis. Rehem et al. (1998) stated that B plays a key role in water and nutrients transportation from root to shoot and they believed that B shortage can causes barren and small stalks in corn and soybean.

\subsection{0 seed mass}

The highest 1000 seed mass was observed in $\mathrm{B}+\mathrm{Zn}+\mathrm{S}$ treatment (Table 2). Zinc is necessary for the biosynthesis of the plant growth regulator such as IAA and for carbohydrate and $\mathrm{N}$ metabolism which leads to high yield and yield components. This may be due to provision of macro and micro nutrients at latter stages which might have improved accumulation of assimilate in seeds and thus resulting in heavier seed. The results of this investigation are in consonance with the findings of Mei et al. (2009) that to effects of B + Mo $+\mathrm{Zn}$ treatment increased 1000 seed mass in rapeseed plant.

These results were in agreement with those reported by Brown et al. (1993), Cakmak et al. (1996), Grewal et al. (1998) and Hosseini et al. (2007) that Zinc application increased thousand grain mass in corn plant. Hemantaranjan and Gray (1988) observed that optimum utilization of $\mathrm{Zn}$ and $\mathrm{Fe}$ significantly increased thousand grain mass in wheat. They declared that total content of carbohydrates, starch, IAA, chlorophyll and seed protein were significantly increased by consumption of these two nutrients. They believe that more production of chlorophyll and IAA can causes delay in plant senescence and prolong the period of photosynthesis. This event improves the production of carbohydrates and their transportation to the growing seeds.

\subsection{Seed oil content}

Analysis of variance showed significant difference among treatments $(p<0.01)$ (Table 1). B $+\mathrm{Zn}+\mathrm{S}$ treatment produced the highest seed oil content. The lowest seed oil content was obtained from control (Table 2). Application of B, Zn and S single or together increased the seed oil content compared with the control, and the increase in oil content with combined nutrients application was higher than that with single application (Table 2). Singh and Sinha (2005) reported the decline in oil concentration may be due to oxidation of some polyunsaturated fatty acids.

The results showed that zinc deficiency would prevent the activity of antioxidant enzymes, leading to widespread and severe damage to lipid membranes, Therefore the lack of zinc can reduce the oil content of seeds (Cakmak, 1997). In the study of sulfur effects on rapeseed have been reported in India that the use of different sulphur sources before flowering increased grain yield and oil content (Sharma et al., 1991). Ahmad et al. (2007) found that sulfur treatment increased the rapeseed oil yield for $20 \mathrm{~kg} \mathrm{ha}^{-1}$. Malhi et al. (2007) showed that sulfur treatment increased oil and protein content.

This might be due to role of sulfur in oil synthesis; sulfur played an important role in the formation of glucosides and glucosinolates (mustard oil). This confirms the findings of Mishra \& Agarwal (1994) in soybean, Ravi et al. (2008) in safflower and Gangadhara et al. (1990) in sunflower.

\section{6 $\mathrm{B}, \mathrm{Zn}$ and $\mathrm{S}$ content in leaves}

$\mathrm{F}$ value and level of significance from ANOVA on content of plant nutrients in rapeseed plant traits are shown in Table 1. B, $\mathrm{Zn}$ and $\mathrm{S}$ contents in plant leaves as affected by $\mathrm{B}, \mathrm{Zn}$ and $\mathrm{S}$ application are shown in Table 2.

Table 3: Mean squares from analysis of variance of antioxidant enzyme activity and fatty acid of rapeseed

\begin{tabular}{|c|c|c|c|c|c|c|c|c|c|}
\hline \multirow[t]{2}{*}{ S.O.V } & \multirow[t]{2}{*}{ df } & \multicolumn{8}{|c|}{ Mean Squares } \\
\hline & & POD & SOD & $\begin{array}{l}\text { Stearic } \\
\text { acid }\end{array}$ & $\begin{array}{l}\text { Palmitic } \\
\text { acid }\end{array}$ & $\begin{array}{l}\text { Oleic } \\
\text { acid }\end{array}$ & $\begin{array}{l}\text { Linoleic } \\
\text { acid }\end{array}$ & $\begin{array}{l}\text { Linolenic } \\
\text { acid }\end{array}$ & Erucic acid \\
\hline Block & 2 & 0.038 & 0.13 & 4.39 & 1.23 & 240.7 & 21.11 & 11.37 & 0.106 \\
\hline Treatment & 7 & $0.058 * *$ & $0.64 * *$ & $1.48^{*}$ & $3.37 * *$ & $1585.2 * *$ & $53.06 * *$ & $28.91 * *$ & $0.064 * *$ \\
\hline Error & 14 & 0.0049 & 0.072 & 0.83 & 0.318 & 88.82 & 1.94 & 3.59 & 0.0015 \\
\hline $\mathrm{Cv}(\%)$ & - & 10.6 & 9.7 & 16.6 & 4.1 & 4.7 & 12.8 & 8.1 & 5.7 \\
\hline
\end{tabular}

ns and *, **: non-significant and significant at $5 \%$ and $1 \%$ probability levels, respectively

POD: Peroxidase SOD: Superoxide dismutase. 
The highest leaf sulphur content $\left(802.6 \mathrm{mg} \mathrm{kg}^{-1}\right)$ was produced from $\mathrm{B}+\mathrm{Zn}+\mathrm{S}$ treatment and minimum (223.97 mg kg ${ }^{-1}$ ) was recorded for control (Table 2). The application of $\mathrm{B}, \mathrm{Zn}$ and $\mathrm{S}$ single treatments increased the leaf sulphur content by a further $226.119 \%$ and $74.6 \%$ compared to the control and the highest leaf sulphur content $\left(802.6 \mathrm{mg} \mathrm{kg}^{-1}\right)$ was obtained from $\mathrm{B}+\mathrm{Zn}+\mathrm{S}$ treatment. $\mathrm{S}$ and $\mathrm{Zn}$ had a grater effect than the application of $\mathrm{B}$.
The highest zinc content was observed in $\mathrm{S}+\mathrm{Zn}$ treatment $\left(49.49 \mathrm{mg} \mathrm{kg}^{-1}\right)$. The smallest zinc content was observed in control (30.31 mg kg-1) (Table 2). Grawel \& Graham (1999) have reported that zinc application increases zinc concentration in seed, roots and leaves. These results were in agreement with those reported by El-Gazzar et al (1979) and Foregoni et al. (1984). Zinc plays an important role in auxine and protein synthesis and it is essential for seed setting (Bybordi \& Mamedov, 2010).

Table 4: Effects of boron (B), zinc (Zn), sulfur (S), and their interactions on antioxidant enzyme activity and fatty acid of rapeseed

\begin{tabular}{|c|c|c|c|c|c|c|c|c|}
\hline Treatment & $\begin{array}{c}\text { POD } \\
\left(\mu \mathrm{mol} \mathrm{g}^{-1} \mathrm{FM}\right. \\
\min )\end{array}$ & $\begin{array}{c}\text { SOD } \\
\left({\left.\text { Unit } \mathrm{mg}^{-1}\right)} \text { ) }\right.\end{array}$ & $\begin{array}{l}\text { Stearic acid } \\
\left(\mathrm{mg} \mathrm{g}^{-1}\right)\end{array}$ & $\begin{array}{l}\text { Palmitic } \\
\text { acid (mg } \\
\left.\mathrm{g}^{-1}\right)\end{array}$ & $\begin{array}{c}\text { Oleic acid } \\
\left(\mathrm{mg} \mathrm{g}^{-1}\right)\end{array}$ & $\begin{array}{c}\text { Linoleic } \\
\text { acid } \\
\left(\mathrm{mg} \mathrm{g}^{-1}\right)\end{array}$ & $\begin{array}{c}\text { Linolenic } \\
\text { acid } \\
\left(\mathrm{mg} \mathrm{g}^{-1}\right)\end{array}$ & $\begin{array}{c}\text { Erucic } \\
\text { acid } \\
\left(\mathrm{mg} \mathrm{g}^{-1}\right)\end{array}$ \\
\hline Control & $0.47^{\mathrm{f}}$ & $8.8^{\mathrm{e}}$ & $6.112^{\mathrm{ab}}$ & $13.27^{\mathrm{c}}$ & $158.3^{\mathrm{e}}$ & $41.41^{\mathrm{e}}$ & $17.11^{\mathrm{d}}$ & $0.878^{\mathrm{a}}$ \\
\hline B & $0.53^{\mathrm{ef}}$ & $9.15^{\mathrm{dc}}$ & $4.542^{b}$ & $13.18^{\mathrm{c}}$ & $197.1^{\mathrm{cd}}$ & $48.03^{\mathrm{cd}}$ & $23.25^{\mathrm{bc}}$ & $0.641^{\text {cd }}$ \\
\hline $\mathrm{Zn}$ & $0.87^{\mathrm{a}}$ & $9.57^{b-d}$ & $5.078^{\mathrm{ab}}$ & $13.77^{\mathrm{bc}}$ & $193.6^{\mathrm{d}}$ & $47.03^{\mathrm{cd}}$ & $22.51^{\mathrm{c}}$ & $0.75^{b}$ \\
\hline $\mathrm{S}$ & $0.64^{\mathrm{c}-\mathrm{e}}$ & $9.47^{\mathrm{cd}}$ & $6.096^{\mathrm{ab}}$ & $12.88^{\mathrm{c}}$ & $188.3^{\mathrm{d}}$ & $46.06^{\mathrm{d}}$ & $22.05^{\mathrm{c}}$ & $0.815^{\mathrm{ab}}$ \\
\hline $\mathrm{B}+\mathrm{S}$ & $0.56^{\mathrm{d}-\mathrm{f}}$ & $9.54^{\mathrm{cd}}$ & $4.833^{\mathrm{ab}}$ & $12.74^{\mathrm{c}}$ & $211.8^{\mathrm{bc}}$ & $52.32^{\mathrm{b}}$ & $23.65^{\mathrm{a}-\mathrm{c}}$ & $0.579^{\mathrm{de}}$ \\
\hline $\mathrm{B}+\mathrm{Zn}$ & $0.74^{\mathrm{bc}}$ & $9.82^{\mathrm{a}-\mathrm{c}}$ & $6.527^{\mathrm{a}}$ & $14.67^{\mathrm{ab}}$ & $227.6^{\mathrm{ab}}$ & $55.55^{\mathrm{a}}$ & $26.58^{\mathrm{ab}}$ & $0.432^{f}$ \\
\hline $\mathrm{S}+\mathrm{Zn}$ & $0.68^{\mathrm{cd}}$ & $10.03^{\mathrm{ab}}$ & $5.151^{\mathrm{ab}}$ & $15.47^{\mathrm{a}}$ & $203.2^{\mathrm{cd}}$ & $48.58^{\mathrm{cd}}$ & $24.45^{\mathrm{a}-\mathrm{c}}$ & $0.661^{\mathrm{c}}$ \\
\hline $\mathrm{B}+\mathrm{S}+\mathrm{Zn}$ & $0.82^{\mathrm{ab}}$ & $10.24^{\mathrm{a}}$ & $5.514^{\mathrm{ab}}$ & $15.14^{\mathrm{a}}$ & $229.6^{\mathrm{a}}$ & $49.48^{\mathrm{c}}$ & $27.14^{\mathrm{a}}$ & $0.557^{\mathrm{e}}$ \\
\hline
\end{tabular}

* Means followed by the same letter(s) in each column are not significantly different $(\mathrm{P}=0.05)$.

POD: Peroxidase SOD: Superoxide dismutase.

The application of single $\mathrm{B}, \mathrm{Zn}$ and $\mathrm{S}$ increased the leaf zinc content by a further 28,36 and $15.4 \%$ compared to the control and the highest leaf zinc content $(53 \%)$ compared to the control was obtained from $\mathrm{B}+\mathrm{Zn}+\mathrm{S}$ treatment (Table 2). At leaf zinc content, sulphur and zinc had a greater impact than the single boron.

The highest boron content was observed in $\mathrm{B}+\mathrm{Zn}+\mathrm{S}$ treatment $\left(24 \mathrm{mg} \mathrm{kg}^{-1}\right)$. The lowest boron content was observed in control (10.21 mg kg-1) (Table 2). These results were in agreement with those reported by Bybordi \& Mamedov (2010) who made the evaluation of application of zinc and iron in oilseed rape.

The application of single $\mathrm{B}, \mathrm{Zn}$ and $\mathrm{S}$ increased the leaf B content by a further $26,30.3$ and $70 \%$ compared to the control and the highest leaf boron content $(135 \%)$ was obtained by the $\mathrm{B}+\mathrm{Zn}+\mathrm{S}$ treatment (Table 2). Regarding leaf boron content, the effects of boron and zinc were more comparable than that of the treatment sulphur.

\subsection{Antioxidant enzyme activity}

Analysis of variance showed that effects of fertilizer treatment on POD and SOD were significant $(p<0.01)$ (Table 3). The highest POD activity was observed in $\mathrm{Zn}$ treatment $\left(0.87 \mu \mathrm{mol} \mathrm{g}{ }^{-1}\right.$ FM.min $)$ while the lowest activity was related to control treatment $(0.47 \mu \mathrm{mol} \mathrm{g}$ FM.min) (Table 4). It seems that $\mathrm{Zn}$ causes the increase of POD activity. Our finding was in agreement with the results reported by Jiang \& Huang (2001) and Habibi et al. (2004).

The role of zinc is known in the effects on the activity of many enzymes (Grotz \& Guerinot, 2006). It seems that zinc enhances the activity of the enzyme POD. The results are consistent with the findings of Jiang \& Huang (2001) and Bybordi \& Mamedov (2010).

The highest POD activity in comparison to the control was observed in $\mathrm{Zn}$ treatment $(85.5 \%)$. The application of $\mathrm{S}, \mathrm{Zn}$ and B singly increased POD activity by a further $36.1,85.5$ and $12.8 \%$ compared to the control. 
The highest POD activity (74.5\%) compared to the control was produced from $\mathrm{B}+\mathrm{Zn}+\mathrm{S}$ treatment (Table 4).

The results showed that $\mathrm{B}+\mathrm{Zn}+\mathrm{S}$ treatment $(10.24$ unit $\mathrm{mg}^{-1}$ ) increased significantly SOD activity. The lowest activity was observed in control $\left(8.8\right.$ unit $\left.\mathrm{mg}^{-1}\right)$ (Table 4). Cacmak (2000) reported that Zn deficiency may inhibit the activities of a number of antioxidant enzymes.

It has been demonstrated that environment stress induces oxidative stress in plant tissues. Exposition of chloroplasts to excessive excitation energy may increases generation of reactive oxygen species and induces the oxidative stress. To overcome the effects of oxidative stress, plants make use of a complex antioxidant system. Relatively higher activity of reactive oxygen species scavenger enzymes have been reported in many stressed plants, which suggests that the antioxidant system plays an important role in plants against environmental stresses (Habibi et al., 2004).

Superoxide dismutase may function as a reactive oxygen species scavenger, by converting $\mathrm{O}_{2}$ to $\mathrm{H}_{2} \mathrm{O}_{2}$ (Baily et al., 2000). Even thought high SOD activity protects plants against superoxide radicals, it can not be considered solely responsible for membrane protection against peroxidation. In general, nutrients application and different effects on antioxidant enzymes activity, in some case increase and in some cases decrease were observed.

The application of single $\mathrm{B}, \mathrm{Zn}$ and $\mathrm{S}$ increased SOD activity to the 7.6, 8.7 and $4 \%$ compared to the control and combined application of two nutrients further enhanced activity of SOD than single nutrient. The highest SOD activity (16.4\%) compared to the control was produced by $\mathrm{B}+\mathrm{Zn}+\mathrm{S}$ treatment (Table 4 ). These results agree with the findings of Bybordi and Mamedov (2010).

\subsection{Fatty acids}

Analysis of variance showed that effects of fertilizer treatment on fatty acids were significant $(p<0.01)$ (Table 3). Rapeseed oil consists of different types of saturated and unsaturated fatty acids (palmitic acid, oleic acid, linoleic acid, linolenic acid, erucic acid, etc.). The palmitic acid and stearic acid are the major saturated fatty acids, whereas oleic and linoleic, linolenic acids are unsaturated. Fatty acid composition of rapeseed in particular and other oil seed crops in general, are influenced by fertilizing management. The findings of present study show that fatty acid composition is affected by $\mathrm{B}+\mathrm{Zn}+\mathrm{S}$ application, for example Bybordi \& Mamedov (2010) found that application zinc and iron increased the percentage of unsaturated fatty acids and decreased saturated fatty acids of rapeseed.

Applications of $\mathrm{B}, \mathrm{Zn}$, and $\mathrm{S}$ resulted in a significant decrease in the erucic acid content compared with the control (Table 4). Analysis of fatty acids by GC showed that, the application of $\mathrm{B}, \mathrm{Zn}$, and $\mathrm{S}$ increased the fatty acids compared to the control (Table 4). The maximum of oleic acid (229.6 mg g $\left.{ }^{-1}\right)$ and linolenic acid $(27.14 \mathrm{mg}$ $\mathrm{g}^{-1}$ ) were obtained from $\mathrm{B}+\mathrm{Zn}+\mathrm{S}$ treatment (Table 4). Maximum of linoleic acid $\left(55.55 \mathrm{mg} \mathrm{g}^{-1}\right)$ were obtained from $B+Z n$ treatment. The highest contents of stearic and palmitic acid were obtained from $\mathrm{B}+\mathrm{Zn}$ and $\mathrm{S}+$ $\mathrm{Zn}$ treatments which were 6.527 and $15.47 \mathrm{mg} \mathrm{g}^{-1}$, respectively. The highest erucic acid content $(0.878 \mathrm{mg}$ $\mathrm{g}^{-1}$ ) was found at control treatment (Table 4).

The increased monounsaturated fatty acid composition associated with the application of $\mathrm{B}, \mathrm{Zn}$, and $\mathrm{S}$ may offer several health benefits. Rapeseed oil with higher levels of monounsaturated fatty acids reduced blood cholesterol levels, thereby reducing the incidence of cardiovascular diseases (Weaver et al., 2000). Such rapeseed oil is also more chemically stable than conventional rapeseed oil because it is less susceptible to oxidation. The use of rapeseed oil with a greater content of monounsaturated fatty acids may improve the food quality of meat (Brown et al., 2000; Cromwell, 2000). Higher levels of monounsaturated fatty acids used in animal feed result in meat products that remain fresher longer, with less oxidation.

\section{CONCLUSIONS}

Regarding to this experiment results, application of Zn, $B$ and S fertilizers with NPK fertilizer can help to increase the yield and yield components in rapeseed. Also fatty acids composition of rapeseed are influenced by nutrients and since quality of edible oils depends on unsaturated fatty acids, especially linoleic and linolenic acids and these acids are essential fatty acids for the human body that must be supplied through diet. Therefore this research showed that we are not only able to increase oil yield with these treatments but we can also increase oil quality with increasing fatty acid content and changed composition. 


\section{REFERENCES}

Ahmad, G., Jan, A., Arif, M., Khattak, R. A. (2007). Influence of nitrogen and sulfur fertilization on quality of canola (Brassica napus L.) under rainfed conditions. Journal of Zhejiang University Science, 8 , 731-737. https://doi.org/10.1631/jzus.2007.B0731

Anderson, J. W. (1975). The function of sulphur in plant growth and metabolism. Pages 87-97 In K. D. McLachlan, (Eds.), Sulphur in Australian agriculture. University Press, Sydney, Australia.

Bailly, C., Benamar, A., Corbineau, F., Come, D. (2000). Antioxidant systems in canola seeds as affected by priming. Seed Science Research, 10(2), 35-42.

https://doi.org/10.1017/S0960258500000040

Beauchamp, C. \& Fridovich, J. (1971). Superoxide dismutase: improved assays and an assay applicable to acrylamide gels. Annual Biochemistry, 44, 276287. https://doi.org/10.1016/0003-2697(71)90370-8

Benton, J. J. (2001). Laboratory guide for conducting soil tests and plant analysis. CRC Press. 363 P. https://doi.org/10.1201/9781420025293

Bole, J. B., \& Pittman, U. J. (1984). Availability of subsoil sulphate to barley and rapeseed. Canadian Journal of Soil Science, 64, 301-312. https://doi.org/10.4141/cjss84-032

Brown, P. H., Cakmak, I., Zhang, Q. (1993). Form and function of zinc in plants. (PP. 93-106). In: A. D. Robson (Eds.), Zinc in soil and plants. Kluwar Academic Publishers. Dordecht, The Netherlands.

Brown, P. H., Bellaloui, N., Wimmer, M. A., Bassil, E. S., Ruiz, J., Hu, H., Pfeffer, H., Dannel, F., Römheld, V. (2002). Boron in plant biology, Plant Biology, 4, 205-223. https://doi.org/10.1055/s2002-25740

Bybordi, A. \& Mamedov, G. (2010). Evaluation of application methods efficiency of zinc and iron for canola (Brassica napus L.). Notulae Scientia Biologicae, 2(1), 94-103.

Cakmak, I. (1997). Effect of different zinc application methods on grain yield and zinc concentration in wheat cultivars grown on zinc-deficient calcareous soils. Journal of Plant Nutrition, 20(4/5), 461-471.

Cakmak, I. (2008). Enrichment of cereal grains with zinc: Agronomic or genetic biofortification? Plant and Soil, 302, 1-17. https://doi.org/10.1007/s11104007-9466-3

Cakmak, I., Kalayci, M., Ekis, H., Brauni, J., Kilinc, Y., Yilmaz, A. (1999). Zn Deficiency as a practical problem in plant and human nutrition in Turkey: a NATO-science for stability project. Field Crop Research, 60, 175-188. https://doi.org/10.1016/S0378-4290(98)00139-7

Cakmak, I., Yilmaz, A., Kalayli, E., Torun, B., Ernoglu, B., Brown, H. J. (1996). Zinc deficiency as a critical problem in wheat production in central Anatolia. Plant and Soil, 180, 165-172. https://doi.org/10.1007/BF00015299

Cara, A. F., Sanchez, E., Ruiz, J. M., Rornero, L. (2002). Is phenol oxidation responsible for the short-term effects of boron deficiency on plasma membrane permeability and function in squash roots? Plant Physiology and Biochemistry, 40, 853858. https://doi.org/10.1016/S0981-9428(02)01447$\mathrm{X}$

Chance, B. \& Maehly, S. K. (1955). Assay of catalase and peroxidase. Methods in Enzymology, 2, 764775. https://doi.org/10.1016/S0076-6879(55)023008

Chen, G., Nian, F. Z., Xu, F. S., Wang, Y. H. (2005). Effect of boron and molybdenum on yield and quality of two rapeseed cultivars. Plant Nutrition Fertility Science, (In Chinese), 11, 243-247.

Chu, T. D., Chen, J. J., Liu, C. Z., Xu, G. B. (1996). Study on reason of floral sterility of rape under boron deficient condition. Plant Nutrition Fertility Science, (In Chinese), 2(1), 23-31.

Clandinin, D. (1981). Canola meal for livestock and poultry. Publication No. 59. Canola Council of Canada, Winnipeg, MB. 25 pp.

Cormwell, G. L. (2000). An animal nutritionalist's view. P. 57-82. In C. F. Murphy and D. M. Peterson (Eds.). Desinging crops for added value. Agron, Monogr. 40. ASA, CSSA, and SSSA, Madison, WI.

Cunnane, S.C. (1995). Metabolism and function of linolenic acid in humans. In: Cunnane, S. C., and L. U. Thompson (Eds.). Flax seed in human nutrition. Pp:99-127. AOCS, Press, Champaign, Illinois, USA.

Das, K., Dang, R., Shivananda, T. N., Sur, P. (2005). Interaction between phosphorus and zinc on the biomass yield and yield attributes of the medicinal plant stevia (Stevia rebaudiana). Science World Journal, 5, 390-395. https://doi.org/10.1100/tsw.2005.49

Dell, B., \& Huang, L. B. (1997). Physiological response of plants to low boron. Plant and Soil, 193, 103120. https://doi.org/10.1023/A:1004264009230 
Dordas, C., \& Brown, P. H. (2005). Boron deficiency affects cell viability, phenolic leakage and oxidative burst in rose cell cultures. Plant Cell Physiology, 268, 293-301. https://doi.org/10.1007/s11104-0040309-1

Fang, Y., Wang, L., Xin, Z., Zhao, L., An, X., Hu, Q. (2008). Effect of foliar application of zinc, selenium, and iron fertilizers on nutrients concentration and yield of rice grain in China. Journal of Agriculture and Food Chemistry, 56, 2079-2084. https://doi.org/10.1021/jf800150z

Foregoni, M., Boselli, M., Bartoletti, C., Dorotea, G. (1984). Effect of iron deficiency or an excess of leaf-applied iron on the mineral and biochemical composition and on the production parameters of chlorotic grapevines. Horticulture Abstract, 54, 95110.

Habibi, D., Boojar, M. M., Mahmoudi, A., Ardekani, M. R., Taleghani, D. (2004). Antioxidative enzymes in sunflower subjected to drought stress. $4^{\text {th }}$ International Crop Sci. Congress, Australia.

Hamm, J.W. (1967). Sulfur on rapeseed and cereals. Papers presented at the Eleventh Annual Manitoba Soil Science Meeting. University of Manitoba, Winnipeg, MB. pp. 91-108.

Hemantaranjan, A., \& Grag, O. K. (1998). Iron and zinc fertilization with reference to the grain quality of Triticum aestivum. Journal of Plant Nutrition, 11(6-11), 1439-1450. https://doi.org/10.1080/01904168809363900

Hosseni, S. M., Maftoun, M., Karimian, N., Rounaghi, A., Emam, Y. (2007). Effect of zinc $\times$ boron interaction on plant growth and tissue nutrient concentration of corn. Journal of Plant Nutrition, 30, 773-781. https://doi.org/10.1080/01904160701289974

Huang, L. B., Pant, J., Dell, B., Bell, R. W. (2000). Effects of boron deficiency on anther development and floret fertility in wheat (Triticum aestivum (Wilgoyne'). Annals of Botany, 85, 493-500. https://doi.org/10.1006/anbo.1999.1095

Gammelvind, L. H., Schjoerring, J. K., Mogensen, V. O., Jensen, C. R., Bock, J. G. H. (1996). Photosynthesis in leaves and siliques of winter oilseed rape (Brassica napus L.). Plant and Soil, 186, 227-236.

Gangadhara, G. A., Manjunathiah, H. M., Satyanarayana, T. (1990). Effect of sulphur on yield, oil content of sunflower and uptake of micronutrient by plants. Journal of the Indian Society of Soil Science, 38, 692-694.
Goldbach, H. E., Yu, Q., Wingender, R., Schulz, M., Wimmer, M., Findeklee, P., Baluska, F. (2001). Rapid response reaction of roots to boron deprivation. Journal of Plant Nutrition and Soil Science, 164, 173-181. https://doi.org/10.1002/15222624(200104)164:2<173::AIDJPLN173>3.0.CO;2-F

Grant, C., Clayton, G. W., Johnston, A. M. (2003). Sulphur fertilizer and tillage effects on canola seed quality in the Black soil zones of western Canada. Canadian Journal of Plant Science, 83, 745-758. https://doi.org/10.4141/P02-107

Grant, C. A. \& Bailey, L. D. (1993). Fertility management in canola production. Canadian Journal of Plant Science, 73, 651-670. https://doi.org/10.4141/cjps93-087

Grewal, H. S., Graham, R. D., Stangoulis, J. (1998). Zinc-boron interaction effects in oilseed rape. Journal of Plant Nutrition, 21(10), 2231-2243. https://doi.org/10.1080/01904169809365557

Grotz, N., \& Guerinot, M. L. (2006). Molecular aspects of $\mathrm{Cu}, \mathrm{Fe}$ and $\mathrm{Zn}$ homeostasis in plants. Biochimica et Biophysica Acta, 1763, 595- 607. https://doi.org/10.1016/j.bbamcr.2006.05.014

Iwai, H., Hokura, A., Oishi, M., Chida, H., Ishii, T., Sakai, S., Satoh, S. (2006). The gene responsible for borate cross-linking of pectin rhamnogalacturonan-II is required for plant reproductive tissue development and fertilization. Proceedings of the National Academy of Sciences of the United States of America.. 103, 16592-16597. https://doi.org/10.1073/pnas.0605141103

Jiang, Y. \& Huang, B. (2001). Drought and heat stress injury to two cool-season turf grasses in relation to antioxidant metabolism and lipid peroxidation. Crop Science, 41, 436-442. https://doi.org/10.2135/cropsci2001.412436x

Kaya, C., \& Higgs, D. (2002). Response of tomato (Lycopersicon esculentum L.) cultivars to foliar application of zinc when grown in sand culture at low zinc. Scientia Horticulturae, 93, 53-64. https://doi.org/10.1016/S0304-4238(01)00310-7

Lieten, P. (2002). Boron deficiency of strawberries grown in subtract culture. Acta Horticulturae, 567, 451-454. https://doi.org/10.17660/ActaHortic.2002.567.94

Liu, W. D. (1999). Microelements nutrition and application of micro-fertilizers (in Chinese). China Agricultural Press. Beijing.

Mc-Grath, S. P., \& Zhao, F. J. (1996). Sulphur uptake, yield response and the interaction between nitrogen 
and sulphur in winter oilseed rape (Brassica napus L.). The Journal of Agricultural Sciences, 126, 5362. https://doi.org/10.1017/S0021859600088808

Malhi, S. S., Schoenau, J. J., Grant, C. A. (2005). A review of sulphur fertilizer management for optimum yield and quality of canola in the Canadian Great Plains. Canadian Journal of Plant Science, 85, 297-307. https://doi.org/10.4141/P04140

Malhi, S. S., \& Gil, K. S. (2002). Effectiveness of sulphate-S fertilization at different growth stages for yield, seed quality and S uptake of canola. Canadian Journal of Plant Science, 82, 665-674. https://doi.org/10.4141/P01-184

Malhi, S. S., Gan, Y., Raney, J. P. (2007). Yield, seed quality and sulfur uptake of Brassica oilseed crops in response to sulfur fertilization. Agronomy Journal, 99, 570-577. https://doi.org/10.2134/agronj2006.0269

Marschner, H. 1995. Mineral nutrition of higher plants. Academic Press. New York.

Marschner, H. 1986. Function of mineral nutrients; Macronutrients, p. 195-267. In: R. J. Haynes (Eds.). Mineral nutrition of higher plants. Academic Press. Orlando, FL.

Mishra, A. K. \& Agarwal, H. P. (1994). Effect of sulphur on growth yield, protein and oil content of soybean. Journal of Oilseeds Research, 11, 99-102.

Matoh, T. (1997). Boron in plant cell walls. Plant and Soil, 193, 59-70. https://doi.org/10.1023/A:1004207824251

Mei, Y., Lei, S. H., Fang-Sen, X., Jian-wei, L.U., YunHua, W. (2009). Effect of B, Mo, Zn, and Their Interactions on Seed Yield of Rapseed (Brassica napus L.). Pedosphere, 19(1), 53-59. https://doi.org/10.1016/S1002-0160(08)60083-1

Nabi, G., Rafique, E., Salim, M. (2006). Boron nutrition of four sweet pepper cultivars grown in borondeficient soil. Journal of Plant Nutrition, 29, 717725. https://doi.org/10.1080/01904160600564543

Neilsen, G. H., Neilsen, D., Hogue, E. J., Herbert, L.C. (2004). Zinc and boron nutrition management in fertigated high density apple orchards. Canadian Journal of Plant Science, 84, 823-828. https://doi.org/10.4141/P03-153

Nuttall, W. F., Ukrainetz, H., Stewart, J. W., Spurr, D. T. (1987). The effect of nitrogen, sulphur and boron on yield and qulity of rapeseed (Brassica napus L. and Brassica compestris L.). Canadian Journal of Soil Science, 67, 545-559. https://doi.org/10.4141/cjss87-051
Nyborg, M., Bentley, C. F., Hoyt, P. B. (1974). Effect of sulphur deficiency. Sulphur Institute Journal, 10, 14-15.

Pandey, N., Pathak, G. C., Sharma, C. P. (2006). Zinc is critically required for pollen function and fertilization in lentil. Journal of Trace Element in Medicine and Biology, 20, 89-96. https://doi.org/10.1016/j.jtemb.2005.09.006

Rathinavel, K., Dharmalingam, C., Paneersel vam, S. (2000). Effect of micronutrient on the productivity and quality of cotton seed cv. TCB 209 (Gossypium barbadense L.). The Madras Agricultural Journal, 86, 313-316.

Ravi, S., Channal, H. T., Hebsur, N. S., Patil, B. N., Dharmatti, P. R. (2008). Effect of sulphur, zinc and iron nutrition on growth, yield, nutrient uptake and quality of safflower (Carthamus tinctorius L.). Karnataka Journal of Agricultural Sciences, 21(3), 382-385.

Rehem, G. W., Fendter, W. E., Overdahi, C. J. (1998). Boron for Minnesota soils. University of Minnesota Ridley, A. O. (1973). Effect of nitrogen and sulfur fertilizers on yield and quality of rapeseed. Papers presented at the $17^{\text {th }}$ Annual Manitoba Soil Science Meeting, University of Manitoba, Winnipeg, MB. pp. 182-187.

Roe, N. E., Stoffella, P. J., Greatz, D. (1997). Comparison of canola (Brassica campestris L.) and (Brassica napus L.) oilseed rape using different growth regulators plant population densities and irrigation treatments. Journal of Agricultural Sciences, 77, 177-187.

Sharma, D. N., Khadar, V. K., Sharma, R. A., Singh, D. (1991). Effect of different doses and sources of sulphur on the quality and yield of mustard (Brassica juncea L.). Journal of the Indian Society of Soil Science, 39, 197-200.

Singh Grewal, H., \& Grahma, R. D. (1999). Residual effects of subsoil zinc and oilseed rape genotype on the grain yield and distribution of zinc in wheat. Plant and Soil, 207, 29-36. https://doi.org/10.1023/A:1004479911399

Singh Grewal, H., Lu, Z. G., Graham, R. D. (1997). Influence of subsoil zinc on dry matter production, seed yield and distribution of zinc in oilseed rape genotypes differing in zinc efficiency. Plant and Soil, $\quad 192, \quad 181-189$. https://doi.org/10.1023/A:1004228610138

Singh, S., \& Sinha, S. (2005). Accumulation of metals and its effects in (Brassica juncea L.) Czern. (cv. Rohini) grown on various amendments of tannery waste, Ecotoxicolgy and Environmental Safety, 62, 
Tayebeh SHOJA et al.

118-127.

https://doi.org/10.1016/j.ecoenv.2004.12.026

Sinha, P., Jain, R., Chatterjee, C. (2000). Interactive effect of boron and zinc on growth and metabolism of mustard commun. Communications in Soil Science and Plant Analysis, 31, 41-49. https://doi.org/10.1080/00103620009370419
Vitosh, M. L., Warnek, D. D., Lucas, R. E. (1997). Boron. Mishigan State University Extension Soil and Management Fertilizer. Available on the http://www.msue.msu.EDV

Zhang, W. Y. (2001). Critical range of soil boron for prognosis of boron deficiency in oilseed rape. Pedosphere, 11(3), 283-288. 